\title{
The Logic of English Saltcod: An Historiographical Revision
}

\section{Olaf U. Janzen}

Ce document traite de la croyance largement répandue que la pêche anglaise à Terre-Neuve s'est spécialisée (en effet, certains disent inventée) dans la salaison qui a produit du poisson sec légèrement salé, car ils ont été contraints de le faire par une pénurie de sel; le corollaire est que les français avaient une abondance de sel bon marché et étaient donc en mesure d'adopter des méthodes de conservation qui gaspillaient d'avantage de sel. Cette perception s'est intégrée dans la littérature historique de Terre-Neuve. Pourtant, il existe des preuves abondantes de contester cette interprétation. L'évidence suggère que la préférence pour le poisson salé français était en fait dictée par les exigences et les défis logistiques du marché ibérique.

\section{Introduction}

Although Newfoundland has often promoted itself as "England's oldest colony" (a claim based both on John Cabot's voyage in 1497 and Sir Humphrey Gilbert's claim in 1583), it is also a fact that fishermen from other parts of Western Europe dominated the fisheries there throughout the sixteenth century. True, there is evidence that the first cargo of North American cod to be delivered to Europe arrived in Bristol in 1502. ${ }^{1}$ But the first fishing voyage to the "new found land" for which there is documentary evidence was a Breton voyage in 1504, and by the time Jacques Cartier arrived in Newfoundland in 1534 on his first voyage of exploration to North America, place-names like "Baye de Brest" and "Blanc Sablon" gave proof that Breton and Norman fishermen had been fishing there in significant numbers for a generation. ${ }^{2}$ Portuguese fishermen appeared by 1506 and a Basque presence materialized soon after. ${ }^{3}$ Contemporary estimates together

1 Peter E. Pope, Fish Into Wine: The Newfoundland Plantation in the Seventeenth Century (Chapel Hill, NC, 2004), 15.

2 Laurier Turgeon, "Le temps des pêches lointaines. Permanences et transformations (vers 1500 - vers 1850)," in Michel Mollat (ed.), Histoire des pêches maritimes en France (Toulouse, 1987), 136; see also Gustave Lanctot, "Thomas Aubert" and "Jean Denys" in George Brown and Marcel Trudel (eds.), Dictionary of Canadian Biography, vol. I, 10001700 (Toronto, 1966; available on-line at $<\mathrm{http}$ ://www.biographi.ca/ $>$ ).

3 Harold A. Innis, The Cod Fisheries; The History of an International Economy (rev. ed.;

The Northern Mariner/le marin du nord, XXIII, No. 2, (April 2013), 123-134 
with surviving records suggest that French fishermen - predominantly Breton and Norman but from other regions as well - may have outfitted 500 vessels for the Newfoundland fishery, with 12,000 fishermen, during the late 1570s, while Basque and Portuguese outfitters equipped between two and three hundred vessels. Against this, fewer than a hundred English vessels sailed annually to Newfoundland - perhaps as few as fifty or even less as late as 1578 , according to one observer. ${ }^{4}$ It was only in the closing decades of the sixteenth century that the English fishery showed signs of significant growth, so much so that by 1593 , Walter Raleigh was able to describe the fishery at Newfoundland as the "stay and support" of the English West Country. ${ }^{5}$

Why did growth of the English fishery lag so much behind the others, then expand so quickly? Finding an answer to this question is critical to this paper, because it will argue that the expansion of the English fishery at Newfoundland was not only shaped by the demand of the market in Continental Europe, but that this market demand also governed the English fishery's choice of curing process. For example, while there were a number of reasons why the English fishery was slower to develop at Newfoundland than those of other countries, one important reason is probably the fact that England already had a well-established cod-fishery at Iceland, one that was based in England's North Sea

Toronto, 1954), 23; David B. Quinn, New American World; A Documentary History of North America to 1602, Vol. I: America from Concept to Discovery. Early Exploration of North America (New York, 1979), 154; Charles de la Morandière, Histoire de la pêche française de la morue dans l'Amérique septentrionale des origines à 1789 (Paris, 1962), I, 219-220. Darlene Abreu-Ferreira maintains that the Portuguese presence in the sixteenth-century fishery has been grossly exaggerated, and that the Portuguese fishery at Newfoundland was not significant at all; see "Portugal's Cod Fishery in the 16th Century: Myths and Misconceptions," in James E. Candow and Carol Corbin (eds.), How Deep Is The Ocean? Historical Essays on Canada's Atlantic Fishery (Sydney, NS, 1997), 31-44. Yet the absence of documentary evidence is not, in itself, evidence of absence. That a significant Portuguese fishery did exist, at least until the 1580 s, is suggested by surviving fiscal records; see Inês Amorim, "The Evolution of Portuguese Fisheries in the Medieval and Early Modern Period: A Fiscal Approach," in Louis Sicking and Darlene Abreu-Ferreira (eds.), Beyond the Catch: Fisheries of the North Atlantic, the North Sea and the Baltic, 900-1850 (The Hague, 2008), 245-279, (esp. 263-265) as well as Amorim's survey of "Portuguese Fisheries, c. 11001830," in David J. Starkey, Jón Th. Thór, Ingo Heidbrink (eds.), A History of the North Atlantic Fisheries, Volume 1: From Early Times to the Mid-Nineteenth Century (Bremen, 2009), 279-298.

4 Anthony Parkhurst estimated in 1578 that the English fleet numbered only thirty to fifty vessels, far fewer than the 150 French vessels, one hundred Spanish ones, and fifty Portuguese ones, in addition to twenty to thirty Basque whaling vessels; Anthony Parkhurst to Richard Hakluyt the Elder, 13 November 1578, in Quinn, New American World, Vol. IV: Newfoundland from Fishery to Colony (New York, 1979), 7-10.

5 Raleigh cited in James E. Candow, "An Overview of the Northwest Atlantic Fisheries, 15021904," in Luc François and Ann Katherine Isaacs (eds.), The Sea in European History (Pisa, 2001), 165. David Quinn maintained that by 1522 there were enough English vessels heading for the Newfoundland fishery to be described as a "fleet," a fleet which "apparently kept growing in numbers"; Quinn, New American World, I, 178-179. 
ports and sufficient for the demands of the English market. ${ }^{6}$ The English fishery at Newfoundland would not experience substantial growth until an existing market developed a greater demand than could be satisfied by existing fisheries, or until a new market appeared somewhere to serve as an incentive capable of encouraging new players, particularly the seaports in England's West Country which would have a locational advantage in a trans-Atlantic fishery, to undertake that commitment. ${ }^{7}$ That incentive materialized in the final quarter of the sixteenth century in response to the decline of the Basque fishing industry at Newfoundland.

That fishing industry has long been misleadingly identified as a "Spanish" fishing industry. ${ }^{8}$ It was in fact a Basque fishery, for it was outfitters of major ports like San Sebastian, Bilbao, and Santander, with the support of numerous smaller ports such as Deba, Portugalete, Renteria and others, who began sending ships and crews to Newfoundland waters sometime in the 1530s. Easy access to forests near the coast as well as close proximity to substantial iron deposits had enabled the Basques to develop a vigorous and innovative tradition of building ships that were capable of oceanic voyages, competitive in price, and superior in quality, while trade in regional products such as wool and iron with northern Europe and with adjacent Spanish provinces provided the risk capital necessary to allow Basque activity in distant fisheries to grow and expand

6 See Wendy R. Childs, "England's Icelandic Trade in the Fifteenth Century: The Role of the Port of Hull," in Poul Holm, Olaf Janzen, Jón Thór (eds.), Northern Seas Yearbook 1995, Association for the History of the Northern Seas (Esbjerg, Denmark, 1995), 11-31; J.Th. Thór, "Foreign Fisheries off Iceland, c. 1400-1800," in Juliette Roding and Lex Heerma van Voss (eds.), The North Sea and Culture (1550-1800): Proceedings of the International Conference held at Leiden 21-22 April 1995 (Hilversum, 1996), 124-134. A brief discussion of the English fishery and the English fish trade at Iceland, including its origins, characteristics, and decline can be found in David B. Quinn, "Columbus and the North: England, Iceland, and Ireland," The William \& Mary Quarterly, 3rd ser., 49, no. 2 (April 1992), 278-297, especially 280-1.

7 The West Country had a well-established and vigorous local fishery which contributed significantly to the regional economy; see Maryanne Kowaleski, "The Expansion of the South-western Fisheries in Late Medieval England," Economic History Review 53, no. 3 (August 2000), 429-454. There is however little evidence of a long-distance West Country fishery or fish trade before the onset of that region's dedication to the Newfoundland fishery. Regina Grafe links the expansion of the English-Iberian saltfish trade with the burgeoning wool trade from Spain to England, Newfoundland fish providing a convenient English export to off-set the cost of Spanish wool imports; see Grafe, Distant Tyranny: Markets, Power and Backwardness in Spain, 1650-1800 (Princeton, 2012), chapter 3, esp. 62-64. Grafe however places the expansion of the English saltfish trade with Iberia much later than do most historians of the trade.

8 See for example Harold Innis, "The Rise and Fall of the Spanish fishery in Newfoundland," Transactions of the Royal Society of Canada, third series, 25 (1931), section ii, 51-70; reprinted in Mary Q. Innis (ed.), Essays in Canadian Economic History (Toronto, 1956), 43 61 and, later, his seminal work, The Cod Fisheries. 
into the 1570s. ${ }^{9}$ For example, the merchants of Burgos played an important role in stimulating the Basque maritime economy. ${ }^{10}$

The focus of this paper, however, is with the role played by market demands in stimulating not only the Basque trans-Atlantic fishery but eventually that of other Europeans. While much of the fish brought back to their home ports by Basque fishing ships was consumed in their own coastal regions, a great deal of the overall production was shipped to inland markets like Pamplona, Burgos, and even Madrid. The result was an intricate and interdependent commercial network in which fish from Newfoundland was just the latest commodity to be added to the commercial pattern. ${ }^{11}$ Yet the strength and vigour of the Basque fisheries did not last. Before the end of the sixteenth century, it had gone into a pronounced decline. Spanish consumers who had become accustomed to having Newfoundland saltfish as a significant element of their diet were now obliged to turn to other European suppliers. ${ }^{12}$

The reasons for that decline are numerous and complex. Spain's wars with its European neighbours - the Dutch revolt as well as wars with England (1585-1604) and France (1595-1598) - led to attacks and harassment of Spanish trade by enemy corsairs. ${ }^{13}$ It also caused Madrid increasingly to requisition merchant shipping for military purposes. The abortive attempt in 1588 to organize a massive coordinated sea-land assault on England was only the greatest of several armadas, all of which were costly to Basque

9 For a comprehensive analysis of Spanish shipping generally, including considerable attention to Basque shipping, see Regina Grafe, "The Strange Tale of the Decline of Spanish Shipping," in Richard Unger (ed.), Shipping and Economic Growth 1350-1850 (Leiden and Boston, 2011), 81-115.

10 The complex network of investment, commerce, shipbuilding, outfitting, and other elements of a maritime economy linking the Basque coast with Burgos was explored by Selma Barkham and Michael Barkham in "The Arriolas of Urazandi: Maritime Enterprise in Viscaya and Guipuzcoa (c. 1540 to c. 1630), in R. Basurto Larrañaga (ed.), Homenaje a Francisco de Abrisketa (Bolibar, 1993), 269-298.

11 Contributing to the strong economic and commercial relationship between Burgos in the interior and Basque seaports, especially Bilbao, was the fact that "the trajectory from Bilbao to Burgos was the shortest and easiest connection between the inland region and the coast"; William D. Phillips, Jr., "Spain's Northern Shipping Industry in the Sixteenth Century," Journal of European Economic History 17, no. 2 (1988), 270.

12 Precisely what generated such a powerful demand for saltfish in Spanish consumers is an entirely different question than the one explored here. This paper takes that demand as a given and concentrates on the English response to that demand. On the decline of the Spanish Basque fishery, see Innis, "Rise and Fall," 43-61. See also Selma Barkham, "Aperçu de l'évolution de la pêche sur les côtes de l'Est canadien," $118^{e}$ congrès national des sociétées historiques et scientifiques (Pau, 1993), 173-180 and Selma Barkham, "Guipuzcoan Shipping in 1571 with Particular Reference to the Decline of the Transatlantic Fishing Industry," Anglo-American Contributions to Basque Studies: Essays in Honor of Jon Bilbao, 13 (1977), 73-81.

13 Problems with piracy and corsairs were as persistent as they were costly, even when Spain was not at war; see Phillips, "Spain's Northern Shipping Industry," 289-291. 
outfitters in terms of personal service and capital which were diverted into the service of the Crown without adequate compensatory reward. ${ }^{14}$ General shipping embargoes imposed by the Crown during these years were just as damaging; fleets that could not sail were fleets that could not earn profits. ${ }^{15}$ Also damaging to the Basque maritime economy were increasingly persistent efforts by the Spanish Crown to control and regulate the regional Basque economy after mid-century. Such regulations interfered with wellestablished and vital commercial links between Spanish Basque and French Basque ports. ${ }^{16}$ It has also been suggested that transformations within the patterns and flows of southern European maritime commerce, together with the structural characteristics of its shipbuilding industry, had a profound impact on the health of the Basque shipping industry. ${ }^{17}$ Finally, the great wealth that began to pour into Spain from Mexico and Peru also played its part, for it encouraged the Madrid government's policies of economic centralization and regulation at the expense of regional economies even as it generated inflationary pressures in the Spanish economy. The cost of outfitting Basque fishing ships rose in Spain to the point where it was cheaper to buy fish from foreign suppliers than to support a fishing industry of one's own.

Spain's loss was England's and France's gain. The volume of trade with Spain by commercial interests in French Basque, Norman, Breton and English ports was already well developed by the 1570 s and persisted even after Spanish hostilities with England formally began in $1585 .{ }^{18}$ Their response to the unsatisfied demand of the Spanish market for cod was therefore predictable. Two-thirds of the vessels destined for Newfoundland out of Bordeaux in the third quarter of the sixteenth century were in fact

14 Barkham and Barkham, "The Arriolas of Urazandi," 283-287. See also Michael Barkham, "Sixteenth Century Spanish Ships and Shipbuilding: The Multipurpose Nao," in Carl Olof Cederlund, Postmedieval Boat and Ship Archaeology: Papers based on those presented to an International Symposium on Boat and Ship Archaeology in Stockholm in 1982 (Stockholm, 1985), 122-123.

15 Barkham and Barkham, "The Arriolas of Urazandi," 287; Phillips, "Spain's Northern Shipping Industry," 291-293; see also Michael M. Barkham, "The Offshore and DistantWater Fisheries of the Spanish Basques, c. 1500-1650," in Starkey, Thór, Heidbrink (eds.), North Atlantic Fisheries, Volume 1, 242.

16 Perhaps nothing better reflects the tension between local sensibilities and Crown preferences and priorities than the on-going efforts of Basque shipbuilders to favour the construction of smaller ships (one hundred to two hundred tons, often even smaller) and those of the Crown to encourage construction of ships of six hundred tons or more; see Phillips, "Spain's Northern Shipping Industry," 276-278. Nevertheless, there was a clear tendency towards the construction of larger ships as the sixteenth century wore on; see Barkham, "Sixteenth Century Spanish Ships," 113, 122.

17 Grafe, "Strange Tale," 106-109; Grafe, Distant Tyranny, 59.

18 Pauline Croft, "Trading with the Enemy 1585-1604," Historical Journal 32, no. 2 (June 1989): 281-302; Pauline Croft, "English Commerce with Spain and the Armada War, 15581603," in M.J. Rodrigues-Salgado and Simon Adams (eds.), England, Spain and the Gran Armada 1585-1604: Essays from the Anglo-Spanish Conferences London and Madrid 1988 (Edinburgh, 1991), 236-263. 
based in French Basque ports, which specialized in the inshore dry cod fishery and trade. ${ }^{19}$ The fishermen of St. Malo also favoured the dry fishery, a preference which became thoroughly entrenched between 1570 and $1575 .{ }^{20}$ In much the same way, and at almost the same time, the English fishery at Newfoundland expanded rapidly, also with a single-minded dedication to saltfish. The expansion of both the French and the English fisheries at Newfoundland was almost certainly triggered by Iberian market demands which could no longer be satisfied by their own ailing fisheries. ${ }^{21}$

Before we go any further, it is necessary to understand that there were several ways in which cod could be cured for market. The oldest may well have been "stockfish," a method by which the fish was caught, cleaned, split, and then air-dried with no use of salt whatsoever. This method was quite common in Iceland. A second, similar method processed fish that had been caught close to shore in small open boats, split it, salted it lightly and then laid it out on the beach or on purpose-built flakes to dry. This technique, producing a product known as "saltfish" or "saltcod," also predated the Newfoundland fishery, though it eventually became so identified with Newfoundland that it was sometimes also called the "Newfoundland" cure. ${ }^{22}$ The process could take several weeks to complete, but it resulted in a product which was both easily transported and could be safely stored for long periods of time without fear of spoiling. The long shelflife of properly cured saltfish made it an attractive product in southern markets. Its light weight also made it easy to transport, a point to which this paper will return. The third method produced what was known as a "wet" or "green" cure. In this method, the fish was gutted and cleaned, then heavily salted. In the early years of the fishery, fish processed this way was caught close to shore, much as fish made into saltcod was caught. When the French developed the offshore banks fishery in the mid-1500s, green cod became the exclusive cure of the banking vessels, with heavily salted cod arranged in layers in the hold; there it remained for considerable lengths of time before it was either processed further or delivered to market. ${ }^{23}$ This green cure became a specialty of French

19 Laurier Turgeon, "Pour redécouvrir notre 16e siècle: les pêches à Terre-Neuve d'après les archives notariales de Bordeaux," Revue d'histoire de l'amérique française 39, no. 4 (printemps 1986), 532.

20 André Lespagnol (ed.), Histoire de Saint-Malo et du pays malouin (Toulouse, 1984), 104.

21 Innis, Cod Fisheries, 19n, 43, 46.

22 We are not sure when the technique of making saltfish was invented. Stockfish was the dominant cure used in Iceland, and predates Newfoundland saltfish, but there is evidence to suggest that Iceland produced both in the fifteenth century; see Pope, Fish Into Wine, 11. Breton fishermen used the lightly salted dry cure for hake in late medieval times; Turgeon, "Le temps des pêches lointaines," 138.

23 The French were the first to develop an offshore banks fishery roughly during the 1550s; see John Mannion and Selma Barkham, Plate 22, "The 16th Century Fishery" in R. Cole Harris (ed.) and Geoffrey Matthews (cartographer/designer), Historical Atlas of Canada, Vol. I: From the Beginning to 1800 (Toronto, 1987); hereafter HAC. See also Pope, Fish Into Wine, 19. There was no English fishery of note on the offshore banks until 1713 and not until after New England fishermen developed one first, directing the inferior product to the less discerning Caribbean market; Pope, Fish Into Wine, 20, 27; James E. Candow, "Salt Fish and 
fishermen who serviced the demands of markets in northern France, notably Rouen and Paris. Those markets were accustomed to that cure since the days of the North Sea cod fishery, long before the Newfoundland fishing grounds had been discovered. ${ }^{24}$ Yet the French also engaged in the production of saltfish (morue sèche) - possibly by the second decade of the $1500 \mathrm{~s}$ - in order to satisfy the developing preference for that product in the markets of southern France. ${ }^{25}$

The fish that English and French shipping began to deliver in quantity to Spanish seaports late in the 1500 s was invariably saltfish - Anthony Parkhurst did claim in 1578 that the Spanish used the wet cure, but that when such fish arrived at their home ports, it was given an additional cure to dry it before being sold and shipped into inland markets. ${ }^{26}$ This preference for saltcod was determined by the needs and preference of Spanish importers and consumers for this kind of cure. ${ }^{27}$ Yet much of the existing literature remains committed to another explanation, one that does not withstand close scrutiny.

Based on Anthony Parkhurst's observation, Harold Innis concluded that the Spanish must have had an abundance of salt which they took in large quantities to Newfoundland, catching their fish off-shore on the banks, cleaning and curing it on board ship before returning home for the final cure. ${ }^{28}$ We know now that this was not so. According to Michael Barkham, the Spanish Basques acquired their salt from Portugal, southern Spain or France, and engaged primarily in a shore-based dry fishery. ${ }^{29}$ But Innis' interpretation led to the notion that the wet cure was embraced by those with an

Slavery in the British Caribbean," in David J. Starkey and James E. Candow (eds.), The North Atlantic Fisheries: Supply, Marketing and Consumption, 1560-1990 (Hull, 2006), 165194, esp. 170-174.

24 Christopher Moore, “The Markets for Canadian Cod in the Eighteenth Century: France's Cod Trade and the Problem of Demand," paper presented at the Canadian Historical Association Annual Meeting, Guelph 1984.

25 Moore maintains that "it was 1517 before cod, and even the name 'morue' (or 'moloue') became known in Bordeaux"; "Markets for Canadian Cod," 6; Jean-François Brière, La pêche française en Amérique du Nord au XVIIIe siècle (Saint-Laurent, PQ, 1990), 54-58.

26 Innis, "Rise and Fall of the Spanish Fishery," 44; also Innis, Cod Fisheries, 38-39. There is evidence to suggest that the practice of giving green cod a dry cure upon arrival in Europe began much earlier. Turgeon refers to a document of St. Malo, dated 1519, which indicates that it had already become a standard practice to dry cod on the beach shingles outside the town; "Le temps des pêches lointaines," 136. Pope suggests that this practice was necessary when it was too late in the season to complete a dry cure in Newfoundland; the fish was then shipped back to Europe where the dry cure would be completed before delivery to consumers; Pope, Fish Into Wine, 27.

27 Pope also maintains that market and consumer preferences determined the cure, rather than the availability of salt. He advises caution, however, noting that too simplistic a dichotomy between markets for wet cod and markets for dry would be misleading.

28 Innis, "Rise and Fall of the Spanish fishery," 51-70.

29 Michael Barkham, "French Basque 'New Found Land' Entrepreneurs and the Import of Codfish and Whale Oil to Northern Spain, c.1580 to c.1620: The Case of Adam de Chibau, Burgess of Saint-Jean-de-Luz and 'Sieur de St. Julien'," Newfoundland Studies 10, no. 1 (Spring 1994), 34, n\#32. 
abundance of salt. Out of this emerged the assumption that a country's preference for using the dry cure or the wet cure was strictly a function of the availability of salt. France had domestic sources of salt and so, it was argued, French outfitters could supply their fishing ships with salt both cheaply and in abundance. The English, in contrast (or so the argument went), had no domestic sources of salt and instead had to purchase it and transport it from overseas sources. Because this allegedly made salt expensive, Innis concluded that the English adopted the dry cure primarily because it used salt much more sparingly. ${ }^{30}$

This conclusion was subsequently picked up by others. Citing Innis, Gillian Cell repeats the argument in her study of English enterprise in late sixteenth-, early seventeenth-century Newfoundland. ${ }^{31}$ Cell, in turn, was used by Ralph Davis to support his assertion that "the English, less lavish with salt in the absence of a good home supply, dry-cured their fish and sold much of it in southern Europe." 32 Neville Oswald repeats the claim in his article on Devon and the English fishery at Newfoundland. ${ }^{33}$ So does John Gilchrist in an article that for many years provided an oft-cited and therefore influential overview of Newfoundland's early history. ${ }^{34}$ Accepting these authorities in good faith, authors of influential survey histories of Canada picked up the claim and passed it on to countless numbers of university undergraduates; one even gave the shortage of salt a deterministic role, to explain why Newfoundland was not settled more quickly, or explored more intensively. ${ }^{35}$ And although academics are beginning to give market factors a stronger role in determining which cure would be favoured, nevertheless, the belief that an abundance of salt gave the French an advantage over the English in the fishery persists in the literature to the present day. ${ }^{36}$

30 Innis, The Cod Fisheries, 35-36; also 49.

31 Gillian Cell, English Enterprise in Newfoundland 1577-1660 (Toronto, 1969), 5, citing Innis, The Cod Fisheries, 48.

32 Ralph Davis, The Rise of the Atlantic Economies (Ithaca, NY, 1973), 82.

33 Neville C. Oswald, "Devon and the Cod Fishery of Newfoundland," Reports and Transactions of the Devonshire Association for the Advancement of Science, Literature \& Art, 115, no. 5 (December 1983), 19-36.

34 John Gilchrist, "Exploration and Enterprise - the Newfoundland Fishery c. 1497-1677," in David Macmillan (ed.), Canadian Business History: Selected Studies, 1497-1971 (Toronto, 1972), 7-26.

35 W.S. MacNutt, The Atlantic Provinces: The Emergence of Colonial Society (Toronto, 1966), 2; R. Douglas Francis, Richard Jones and Donald B. Smith, Origins: Canadian History to Confederation (4th. ed.; Toronto, 2000), 39. Kenneth Norrie and Douglas Owram give salt a deterministic role in A History of the Canadian Economy (Toronto, 1991), 54.

36 Both David Starkey and Glanville Davies assume that the French had an advantage in the fishery because of an alleged abundance of salt, compared with the English. See David Starkey, "Devonians and the Newfoundland Trade," in Michael Duffy et al, The New Maritime History of Devon, Volume I: From Early Times to the Late Eighteenth Century (London, 1993), 163; Glanville Davies, England and Newfoundland: Policy and Trade 1660$1783(\mathrm{PhD}$ thesis, University of Southampton, 1980), 242. In his otherwise authoritative survey history of Newfoundland and Labrador, Sean Cadigan maintains that "The Basques ... 
If such an argument can permeate works of an academic nature, it should then come as no surprise that works written for a more general audience have accepted it as well. Thus, Samuel Eliot Morison assures us that an abundance of salt meant that Spanish, Portuguese and French Biscayers favoured green cod, while English and Irish fishermen, "having to import salt," favoured the dry fishery; Norman and Bretons had plenty of "cheap salt" and so they practised both. ${ }^{37}$ Fred Rowe made the same assumption in his survey history of Newfoundland and Labrador. ${ }^{38}$ Brian Fagan also dwells on the fact that saltcod "required less salt and was cheaper to process." ${ }^{39}$ Mark Kurlansky goes so far as to insist that the shortage of salt actually inspired the English to invent the technique of making saltfish. ${ }^{40}$ Shannon Ryan - an academic purposively writing for the general reader - perpetuates the traditional interpretation. ${ }^{41}$ That Internet websites have also embraced the conclusion that the English were obliged by shortages of salt to use the dry cure seems almost an inevitability. ${ }^{42}$

Yet with careful scrutiny, this argument begins to fall apart. For one thing, no one has studied the salt trade sufficiently to determine what the costs of salt were, whatever the source. ${ }^{43}$ Nor is there any evidence in the documentary record of complaints about the cost or availability of salt. True, in his Discourse and Discovery of New-Found-Land, first published in 1620, Richard Whitbourne, stressed the expense of salt but only to support a proposal to produce salt in Newfoundland. ${ }^{44}$ Nowhere did he

dominated the European cod fishery since medieval times because they had access to plentiful supplies of salt"; see Newfoundland and Labrador: A History (Toronto, 2009), 32.

37 S.E. Morison, The European Discovery of America: The Northern Voyages (New York, 1971), 473-478.

38 Fred Rowe, A History of Newfoundland and Labrador, (Toronto, 1980), 100.

39 Brian Fagan, Fish on Friday: Feasting, Fasting, and Discovery of the New World (New York, 2006), 230.

40 Mark Kurlansky, Cod: A Biography of the Fish That Changed the World (Toronto, 1997), 5455.

41 Shannon Ryan, A History of Newfoundland in the North Atlantic to 1818 (St. John's, NL, 2012), 13. His goal of writing for students and general readers is explained on p. xii.

42 History of the Northern Cod Fishery $<$ http://www.cdli.ca/cod/history5.htm> (accessed 1 May 2012): "The Spanish, Portuguese and French, concentrated on fishing on the Banks off Newfoundland where fish could always be found; the catch was salted on board the ships and brought back to Europe to be dried and sold. Even when they fished near shore these fishermen usually used abundant supplies of salt. The English fishermen did not have access to the supplies of salt that were available to the others and could not salt their fish to the same extent. They, however, were able to develop a system which combined light salting for a short period, followed by thorough washing, and then drying in the open air. The result was the light-salted product for which Newfoundland eventually became famous."

43 Labour costs should also be factored into the equation, and to my knowledge, no one has yet made the attempt. The labour costs of making saltcod must have been substantial, given the complexity and time that the process required, as opposed to the production of wet cod.

44 Cell collates the editions of 1620, 1622 and 1623 in her edited collection, Newfoundland Discovered: English Attempts at Colonization, 1610-1630 (London, 1982); see especially p. 142. 
suggest that English fishermen were handicapped by salt that was more costly and less abundant than salt available to fishermen of other nations. Instead, salt was readily available both to the French and to the English. It was a common cargo, together with nuts, fruits, cork, and especially wine, of ships returning from Spain and Portugal after delivering their cargoes of fish. It is even possible to argue that salt was more expensive for French fishermen, because the elaborate structure of salt taxes in that country led to tremendous variations in salt prices from one region to the next. ${ }^{45}$

The most important factor in determining what cure would be preferred by fishermen was not the cheapness or availability of salt, but rather, the preference of the particular market they planned to supply. The English favoured the dry cure almost certainly because they were completely committed to servicing the Iberian and southern European markets, where saltfish was preferred. French fishermen produced wet cod for those markets in northern France that preferred it, just as French fishermen also produced dry saltcod for those markets where that was preferred. Indeed, by the end of the sixteenth century, and for the next two hundred years, France would be divided into two distinct regions according to consumer preference for wet or dry cod. An approximate dividing line between regional preferences was provided by the Loire River: north of the Loire, French consumers continued to prefer wet fish; south of the Loire, consumers demanded saltcod. And to satisfy this demand, French fishermen produced both kinds of fish. ${ }^{46}$ Yet whatever cure was favoured by the market, ultimately it was price that governed sales, for sales dropped whenever prices rose. ${ }^{47}$

Although the European fisheries at Newfoundland tend to be intimately associated with certain key seaports (both for outfitting and for delivery of the season's production), it is imperative that we not lose sight of the fact that the principal European markets tended to be urban centres, often located some distance inland. In France, the biggest market for green cod was Paris, consuming as much as seventy-five percent of the total green cod produced by the bank fishery. ${ }^{48}$ Similarly, much of the fish delivered to Spanish seaports like Santander and San Sebastian was then transported inland to satisfy the high demand for fish of urban markets like Burgos and Madrid. But unlike France, northern Spain lacked rivers that would enable bulk cargoes like fish to be delivered to interior destinations efficiently by water. The coast was in fact quite rugged, so that fish had to be carried by mule trains over primitive trails and roads. While saltfish had other desirable qualities - such as its long shelf-life - the logistical challenge of

45 Jean-François Brière, "The French Fishery in the $18^{\text {th }}$ Century," in Candow and Corbin (eds.), How Deep Is The Ocean?, 47-64. Peter Pope maintains that English outfitters had easy access to cheap salt in Biscay and Iberia; Fish Into Wine, 12, also 14-15. According to Pope, "salt for the fishery was neither difficult to obtain nor particularly costly .... Thus, dependence on imported salt is not a plausible explanation for West Country reliance on the dry cure...."; 15.

46 Mannion \& Barkham, "The Sixteenth Century Fishery," HAC, I, Plate 22.

47 Moore, "Markets for Canadian Cod," 9.

48 This was especially the case for green cod in France; see Moore, "Markets for Canadian Cod," 5-6; see also Innis, The Cod Fisheries, 89. 
moving cod from receiving port to inland consumers was a critical reason which obliged the Spanish market to develop its preference for saltfish. Because it was light enough to be shipped by mule train in significant quantities, only saltfish could arrive at towns in the interior and still be cheap enough to be affordable to consumers. ${ }^{49}$

The relationship between the logistics of overland transportation and the preference in Iberia for lightweight saltfish may seem incredibly obvious, yet as Santiago Piquero and Ernesto López observe in the opening sentence of a recent article, "Despite the important place that dried, salted cod has occupied in Spanish diet and cuisine, it has received surprisingly little attention in the historiography of Spanish consumption and food prices. ${ }^{50}$ Fortunately, that has begun to change. There is increased attention being given by a new generation of historians to the way in which market prices and consumer preferences were shaped by the logistical costs of transporting cod from receiving port to the market. In France, for example, the major receiving ports for green cod were those with easiest access to the Parisian market. Though merchants blamed the high cost of delivering fish to that market on taxes and excise duties, the cost of transportation was the real culprit. ${ }^{51}$ And France at least was blessed with a number of rivers in servicing interior markets. How different the situation was in Spain. There, fish destined for consumers in the urban markets of the interior had to be transported by road, for there were no rivers. As a result, according to one calculation, the cost of moving saltfish from coastal receiving ports to Spanish inland markets in the middle of the seventeenth century was twenty-five times greater than the cost of transporting saltfish across the Atlantic in the first place. ${ }^{52}$ This surely was a compelling reason in its own right for Spanish markets to favour lightweight saltfish. Indeed, so powerful did that preference become that, just as in other markets for saltcod such as Portugal and southwestern France, Spain -

49 According to one Spanish historian, “... saltfish ... would meet the two conditions of being cheap and easy to preserve and store. These were indispensable characteristics due to the high cost of transporting fish into the interior of Castile." Román Basurto Larrañaga, Comercio y Burguesia Mercantil de Bilbao en la Segunda Mitad del Sigo XVIII (Bilbao, 1983), Chapter 4, "La Negociacion del Bacalao. Relaciones Comerciales entre Bilbao y Terranova en la Segunda Mitad del Siglo XVIII," 205. William Phillips also emphasizes the degree to which topography shaped the nature and volume of trade between the coast and the interior; see Phillips, "Spain's Northern Shipping Industry," 269.

50 Santiago Piquero and Ernesto López, "New Evidence for the Price of Cod in Spain: The Basque Country, 1560-1900," in Starkey and Candow (eds.), The North Atlantic Fisheries, 195.

51 Brière, La pêche française, 27-28 and chapter 10. See also Moore, "Markets for Canadian Cod," 8-10.

52 Regina Grafe, "Turning Maritime History into Global History: Some Conclusions from the Impact of Globalization in Early Modern Spain,” in Maria Fusaro and Amélia Polónia (eds.), Maritime History as Global History (St. John's, NL, 2010), 249-266. See especially Tables 1 $\&$ 2, 258-259. See also her essay, "The globalisation of codfish and wool: Spanish-EnglishNorth American triangular trade in the early modern period," London School of Economics Economic History Working Paper Series, Working Paper No. 71/03 (<http://www2.lse.ac.uk/ economicHistory/pdf/wp7103.pdf>; 2003). Grafe's research is now available as a monograph, Distant Tyranny. 
particularly the Basque region - developed a cuisine in which saltfish became a key ingredient in many dishes. ${ }^{53}$ We can only hope that this attention to the factors which shaped consumer preferences will go far in offsetting the primacy given until now by the literature to the characteristics of production in the fishery.

\section{Conclusion}

Thus, several factors converged in the sixteenth century which account for the English dedication to the production of saltfish. Of these, perhaps the most important was the logistical challenges of delivering fish from Basque seaports to the inland markets of Castile, challenges which had committed Spain at a very early stage to a preference for saltfish. This, combined with the rapid decline of the Basque fishery late in the sixteenth century, created an opportunity for foreign suppliers, not only English but also French, to expand their own fisheries at Newfoundland in order to satisfy persistent Spanish demand for saltfish.

53 To this day, many of those dishes are prepared "mule driver style" in recognition of the way that saltfish was carried into the interior and the way in which saltfish dishes were routinely consumed by the mule drivers. One such dish - "bacalhao al ajo arriero" (cod and potato puree, mule driver's style) - figures prominently in the recipes assembled in Janet Mendel, My Kitchen in Spain: 225 Authentic Regional Recipes (New York, 2002), 233. As Ms Mendel explains in her introduction to this recipe, "Long before trucks and railroads transported freight from seaports to inland cities, mule drivers made the long overland trek, stopping for food and lodging en route at ventas (roadside inns), the truck stops of yore, for food and lodging. Many dishes across Spain are prepared in 'mule driver's style'." 